\title{
FAKTOR-FAKTOR YANG BERHUBUNGAN DENGAN POLA PENCARIAN PENGOBATAN KE PELAYANAN KESEHATAN ALTERNATIF PASIEN SUSPEK TUBERCULOSIS DI KOMUNITAS
}

\author{
Kristiono R.S, Yuniar Wardani \\ Fakultas Kesehatan Masyarakat, Universitas Ahmad Dahlan Yogyakarta \\ tsaqifa_kholida@yahoo.com
}

\begin{abstract}
ABSTRAK
Latar Belakang : Angka penemuan kasus Tuberculosis (TB) di Propinsi DIY pada tahun 2009 baru mencapai 52,90\% (target 70\%). Penemuan pasien TB di unit pelayanan kesehatan masih secara pasif, sehingga pola perilaku pencarian pengobatan pasien TB ataupun suspek TB sangatlah penting dipahami. Penelitian yang dilakukan sebelumnya menunjukkan bahwa $43 \%$ suspek TB mencari pengobatan di pelayanan kesehatan alternatif. Penelitian ini bertujuan mengetahui faktor-faktor yang berhubungan dengan pola pencarian pengobatan ke pelayanan kesehatan alternatif suspek TB di komunitas.

Metode : Penelitian ini menggunakan pendekatan cross sectional. Sampel penelitian menggunakan total sampel cluster sebesar 750 responden. Responden diambil secara acak dengan menggunakan prosedur survei cepat. Analisis data yang dipergunakan adalah analisis univariat dan analisis bivariat.

Hasil : Secara statistik, tidak ada hubungan antara jenis kelamin, pendidikan, umur dan status ekonomi dengan pola pencarian pengobatan alternatif. Hal ini dapat dilihat dari nilai $P$ value yang semuanya menunjukkan angka lebih besar dibandingkan 0.05. Secara biologis, jenis kelamin laki-laki merupakan faktor protekif pengampilan keputusan suspek TB untuk tidak melakukan pengobatan. Jenis kelamin laki-laki mempunyai resiko 0,708 kali dibanding perempuan untuk berobat ke apotik/toko obat. Hal ini ditunjukkan dari nilai Ratio Prevalen (RP) $=0,708$ (dengan $\mathrm{Cl}$ 95\%:0,471 - 1,066). Variabel pendidikan, umur dan status ekonomi mempunyai nilai nilai Ratio Prevalen (RP) $>1$ artinya bahwa umur lansia belum tentu merupakan faktor resiko pengambilan keputusan suspek TB untuk melakukan pengobatan alternatif.

Kesimpulan : Tidak ada hubungan antara pendidikan, status ekonomi, jenis kelamin, dan umur dengan pola pencarian pengobatan ke pelayanan kesehatan alternatif.
\end{abstract}

Kata Kunci : Tuberculosis, pencarian pengobatan, pelayanan kesehatan alternatif

\begin{abstract}
Background : Daerah Istimewa Yogykarta (DIY) in TB case detection rate in 2009 reached $52.90 \%$ (target $70 \%$ ). The discovery of TB patients in the health care unit is still passive, so the pattern of health seeking behavior of TB or suspected TB patients is very important to understand. Past research indicates that $43 \%$ of TB suspects to seek treatment in alternative health care. This study aimed to determine the factors associated with treatment seeking patterns of alternative health services to suspected tuberculosis in the community.

Methods : This study used a survey method with cross-sectional design. Total study sample using cluster sample of 750 respondents. Respondents were drawn at random by using a quick survey procedures. Analysis of the data used were univariate and bivariate analysis.

Results : There were not relationship between gender, education, age and economic status of the search patterns of alternative medicine. It can be seen from the value $P$ value indicates the number of which are smaller than 0.05. Biologically, male gender was a factor suspected
\end{abstract}


tuberculosis protekif pengampilan decision not to take medication. Male sex had 0.708 times the risk than women to go to a pharmacy / drug store. It is shown from the values prevalent Ratio ( $R P)=0.708$ ( with $95 \% \mathrm{Cl}: 0.471$ to 1.066 ). Variables of education, age and economic status have values prevalent Ratio $(R P)>1$ means that the age of the elderly is not necessarily a risk factor for tuberculosis suspects decision to perform alternative medicine.

Conclusion : There were not relationship between education, economic status, the sex, and age at treatment seeking patterns to alternative health care.

Keyword : Tuberculosis, treatment seeking, alternative health care

\section{PENDAHULUAN}

Indonesia sebagai negara dengan jumlah kasus terbesar nomor tiga di dunia, berusaha untuk memenuhi target global dan berhasil mencapai target penemuan kasus dan pengobatan pada tahun 2006. Akibat yang terjadi, survei prevalensi TB terakhir yang dilakukan menunjukkan adanya perbaikan yang nyata dalam program pengendalian TB. Data surveilans TB menunjukkan bahwa target tersebut tidaklah merata secara nasional, karena penemuan kasus TB diberbagai propinsi mempunyai variasi yang sangat besar. Target Indonesia untuk mencapai MDG memerlukan upaya ekstra disamping upaya untuk meningkatkan penemuan kasus. Proses penemuan pasien TB dilakukan secara pasif, maka perilaku pencarian pengobatan pasien TB menjadi faktor yang penting bagi kesuksesan program pengendalian penyakit TB di Indonesia ${ }^{1}$.

Di Propinsi DIY angka penemuan kasus TB masih rendah dimana pada tahun 2009 baru mencapai 52,90\% (target 70\%). Angka tersebut masih belum beranjak membaik dengan capaian di tahun 2008 yang baru mencapai 51,97 \% . Penderita TB yang tidak sembuh atau penderita yang tidak memperoleh pengobatan karena belum ditemukan, merupakan sumber penular yang mengancam pencapaian derajad kesehatan mengingat penyakit TB disamping dapat menimbulkan kematian yang tinggi juga menjadi prekursor berbagai penyakit dengan fatal lain seperti HIV/AIDS, penyakit paru obstruksi, dan lain sebagainya (Profil Kesehatan Propinsi DIY 2009). Cara penemuan pasien TB di unit pelayanan kesehatan masih secara pasif (pasif case finding), sehingga pola pencarian pengobatan pasien TB ataupun suspek TB sangatlah penting dalam program penanggulangan TB di Indonesia.

Beberapa penelitian menunjukkan beberapa faktor yang berhubungan dengan pola pencarian pengobatan, khususnya pengobatan TB. Penelitian yang berjudul Faktor-Faktor yang Berhubungan dengan Perilaku Pencarian Pertolongan Pengobatan Tersangka Penderita TB paru di Wilayah Kecamatan Banggai Kabupaten Banggai Kepulauan Tahun 2000 menunjukkan faktor persepsi akibat, persepsi kegawatan dan tingkat pendidikan berhubungan dengan perilaku pencarian pertolongan pengobatan tersangka penderita TB paru di wilayah kecamatan Banggai kabupaten Banggai Kepulauan². Survei Perilaku Mencari Pengobatan Individu dengan Gejala Batuk Lebih dari 2 Minggu (Penelitan Komunitas), menunjukan bahwa $11 \%$ suspek TB yang diwawancara belum pernah mencari pengobatan. Sedangkan dari Suspek TB yang telah berobat, $46 \%$ langsung mengunjungi layanan kesehatan modern dan berarti masih ada $43 \%$ yang mencari pengobatan alternatif ke apotik, pengobatan tradisional dan toko obat $^{3}$.

Sarana pelayanan kesehatan di Provinsi Yogyakarta relatif cukup banyak baik dari segi jumlah maupun jenisnya. Sarana pelayanan kesehatan dasar milik pemerintah (Puskesmas) telah menjangkau keseluruhan kecamatan yang ada di kabupaten / kota bahkan jika digabungkan dengan puskesmas pembantu sebagai jaringan pelayannya, telah mampu menjangkau seluruh desa yang ada, tapi masih

KESMAS Vol. 7, No. 2, September 2013: 55-112 
ada suspek TB yang mencari pengobatan ke pelayanan kesehatan alternatif. Pengobatan ke pelayanan kesehatan alternatif hanya mengobati gejalanya saja, dan tidak dilakukan diagnosis terlebih dahulu. Hal ini akan berakibat gejala menghilang tapi kuman TB masih bersembunyi di dalam tubuh ( Dorman) dan sewaktu-waktu jika kondisi tubuh lemah akan menyerang lagi. Kuman TB akan mati hanya dengan pengobatan TB dan sebelum dilakukan pengobatan TB perlu dilakukan pemeriksaan diagnosis untuk menentukan apakah TB atau bukan. Proses diagnosis ini hanya dapat dilakukan di pelayanan kesehatan modern dan belum ada di pelayanan kesehatan tradisional, karena keterbatasan peralatan dan tenaga yang melakukannya. Dengan diagnosis yang tepat akan menentukan obat dan dosis yang tepat serta tidak hanya menghilangkan gejala saja tapi dapat menghilangkan penyebab dari penyakit tersebut, hal ini hanya dapat dilakukan di pelayanan kesehatan modern.

Tujuan penelitian ini adalah mengetahui faktor-faktor yang berhubungan dengan pola pencarian pengobatan ke pelayanan kesehatan alternatif suspek TB di komunitas. Tujuan khususnya adalah mengetahui hubungan jenis kelamin dengan pola pencarian pengobatan ke pelayanan kesehatan alternatif suspek TB di komunitas, mengetahui hubungan pendidikan dengan pola pencarian pengobatan ke pelayanan kesehatan alternatif suspek TB di komunitas, mengetahui hubungan status ekonomi dengan pola pencarian pengobatan ke pelayanan kesehatan alternatif suspek TB di komunitas dan mengetahui hubungan umur dengan pola pencarian pengobatan ke pelayanan kesehatan alternatif suspek TB di komunitas.

\section{METODE PENELITIAN}

Penelitian ini menggunakan metode survei dengan pendekatan cross sectional dengan melakukan survei yang dilakukan terhadap suspek TB yang ada di populasi di tiga kabupaten yaitu Kabupaten Bantul, Kabupaten Sleman, dan Kotamadya Yogyakarta. Sampel penelitian adalah Populasi dengan gejala TB yang ada di tiga kabupaten yaitu Kabupaten Bantul, Kabupaten Sleman dan Kota Yogyakarta dan memenuhi kriteria. Kriteria inklusi dalam penelitian ini adalah individu usia 15 tahun keatas yang ditemukan dalam proses data koleksi di masyarakat, mempunyai gejala batuk minimal dua minggu atau lebih dan bersedia menandatangi informed consent. Kriteria eklusinya adalah pasien yang telah terdiagnosis dengan penyakit paru kronis lainnya (asma, Penyakit Paru Kronis Obstruktif) dan mengalami gangguan kejiwaan/intelektual dan tuli sehingga mengganggu jalannya penelitian.

Total sampel cluster sebesar 193 sampel di 30 cluster. Total sampel setiap cluster $193 / 30=7$ sampel di setiap cluster. Total sampel $7 \times 30=210$. Namun dalam penelitian ini sampel tiap cluster menjadi 15 dengan jumlah cluster menjadi 50. Jadi total sampel dalam penelitian ini menjadi $15 \times 50=750$ sampel. Responden diambil secara acak dengan menggunakan prosedur survei cepat yang dikembangkan oleh WHO/EPI. Teknik sampling klaster bertahap digunakan untuk pengambilan sampel. Tahap pertama dilakukan dengan memilih desa yang ada di ketiga kabupaten tersebut secara acak. Besar sampel disetiap desa diambil dengan pendekatan probability proportionate to size. Tahap kedua dilakukan dengan memilih rumah tangga yang ada di desa tersebut secara acak dan selanjutnya, individu dengan gejala batuk lebih dari dua minggu diidentifikasi dari rumah-kerumah hingga target besar sampel dipenuhi untuk desa tersebut. Analisis data yang dipergunakan adalah analisis univariat dan analsisi bivariat. 


\section{HASIL PENELITIAN DAN PEMBAHASAN}

\section{A. Hasil Penelitian}

Hasil analisis univariat didapatkan dengan menghitung distribusi frekwensi variabel pola pencarian pengobatan, jenis kelamin, status pendidikan dan tersaji dalam Tabel 1.

Tabel 1. Distribusi Frekwensi berdasarkan karakteristik responden.

\begin{tabular}{lcc}
\hline \multicolumn{1}{c}{ Variabel } & N & $\%$ \\
\hline Pola pencarian pengobatan & & \\
a. Pengobatan tradisional & 85 & 24,1 \\
b. Apotik/toko obat & 267 & 75,9 \\
Jenis kelamin & & \\
a. Laki-laki & 135 & 38,4 \\
b. Perempuan & 217 & 61,6 \\
Status pendidikan & & \\
a. Rendah & 275 & 78,1 \\
b. Tinggi & 77 & 21,9 \\
Status ekonomi & & \\
a. Miskin & 292 & 83 \\
b. Kaya & 60 & 17 \\
Umur & & \\
a. Lansia & 150 & 42,6 \\
b. Belum lansia & 202 & 57,4 \\
Total & 352 & 100 \\
\hline
\end{tabular}

Berdasarkan Tabel 1 dapat disimpulkan bahwa sebagian besar responden cenderung memilih pergi ke apotik/toko obat sebagai pola pencarian pengobatan, jenis kelamin perempuan, berpendidikan rendah, sosial ekonomi miskin dan berada pada usia dewasa (belum masuk kelompok usia lansia).

Analisis bivariat merupakan analisis hubungan antara variabel yang bertujuan untuk mengetahui hubungan antara variabel bebas dan variabel terikat. Uji statistik yang digunakan untuk menguji hubungan antara variabel adalah uji Chi Square $\left(X^{2}\right)$. Hasil analisis bivariat dapat dilihat dari Tabel 2.

Tabel 2. Hasil analisis bivariat antara variabel jenis kelamin, status pendidikan, status ekonomi, umur dan pola pencarian pengobatan.

\begin{tabular}{|c|c|c|c|c|c|c|}
\hline \multirow{3}{*}{ Variabel } & \multicolumn{4}{|c|}{ Pola pencarian pengobatan } & \multirow{3}{*}{$\begin{array}{c}\mathrm{RP} \\
(95 \% \mathrm{Cl})\end{array}$} & \multirow{3}{*}{$P$} \\
\hline & \multicolumn{2}{|c|}{ Tradisional } & \multicolumn{2}{|c|}{$\begin{array}{c}\text { Apotik/Toko } \\
\text { Obat }\end{array}$} & & \\
\hline & $\mathrm{n}$ & $(\%)$ & $\mathrm{n}$ & $(\%)$ & & \\
\hline \multicolumn{7}{|l|}{ Jenis Kelamin } \\
\hline a. Laki-laki & 26 & 30.6 & 109 & 40,8 & 0.71 & \multirow{3}{*}{0.91} \\
\hline b. Perempuan & 59 & 69.4 & 158 & 59,2 & $(0.5-1.1)$ & \\
\hline Status Pendidikan & & & & & & \\
\hline a. Rendah & 71 & 83.5 & 204 & 76,4 & 1.42 & \multirow{2}{*}{0.17} \\
\hline b. Tinggi & 14 & 16.5 & 63 & 23,6 & $(0.9-2.4)$ & \\
\hline \multicolumn{7}{|l|}{ Status Ekonomi } \\
\hline a. Miskin & 74 & 87.1 & 218 & 81,6 & 1.38 & \multirow{2}{*}{0.25} \\
\hline $\begin{array}{r}\text { b. Kaya } \\
\text { Umur }\end{array}$ & 11 & 12.9 & 49 & 18,4 & $(0.8-2.4)$ & \\
\hline \multicolumn{7}{|l|}{ Umur } \\
\hline b. Belum lansia & 42 & 50.4 & 159 & $\begin{array}{l}40,0 \\
59 ?-3 r(-2)\end{array}$ & $(0.019)$ & \multirow[t]{2}{*}{0.15} \\
\hline Total & 85 & 100 & 267 & 100 & & \\
\hline
\end{tabular}


Hasil analisis statistik antara variabel jenis kelamin dengan pola pencarian pengobatan, antara status pendidikan dengan pola pencarian pengobatan, antara status ekonomi dengan pola pencarian pengobatan dan antara umur dengan pola pencarian pengobatan, kesemuanya menunjukkan tidak adanya hubungan. Hal ini dapat dilihat dari nilai $p>0.05$.

\section{B. Pembahasan}

Jenis kelamin perempuan lebih banyak mengambil keputusan untuk berobat ke alternatif dibanding laki-laki. Perempuan juga banyak yang mencari pengobatan ke apotik/toko obat ketika gejala muncul. Menurut pengamatan peneliti karena pengetahuan tentang bahaya TB yang kurang, sehingga dalam mencari pengobatan, suspek TB mencari pengobatan yang cepat dan mudah dijangkau. Pengobatan hanya dilakukan hanya untuk menghilangkan gejala saja, padahal TB tidak dapat diobati secara sembarangan. Perlu proses yang panjang untuk penegakkan diagnosis dan pengobatan. Berdasarkan pengamatan peneliti suspek TB baik laki-laki-laki atau perempuan, gejala yang diderita saat ini mereka merasa masih mampu untuk beraktivitas sehari-hari dan dari pengalaman masa lalu dengan gejala yang sama masih dapat diobati dengan pengobatan sendiri seperti pergi ke alternatif atau ke apotik/toko obat. Padahal dengan gejala yang sama belum tentu diagnosisnya juga sama, sehingga perlu proses diagnosis untuk dapat menentukan obat yang tepat.

Besarnya resiko dapat dilihat dari nilai Ratio Prevalen $(\mathrm{RP})=0,708$ (dengan $\mathrm{Cl} 95 \%$ : 0,471 - 1,066) dengan demikian Ratio Prevalen $<1$ dan rentang nilai interval kepercayaan mencakup angka 1 yang berarti bahwa jenis kelamin laki-laki merupakan faktor protekif pengampilan keputusan suspek TB untuk tidak melakukan pengobatan. Jenis kelamin laki-laki mempunyai resiko 0,708 kali dibanding perempuan untuk berobat ke apotik/toko obat.

Alasan masyarakat melakukan pengobatan sendiri karena orang atau masyarakat tersebut sudah percaya kepada dirinya sendiri, dan sudah merasa bahwa berdasarkan pengalaman yang lalu usaha pengobatan sendiri sudah dapat mendatangkan kesembuhan. Hal ini mengakibatkan pencarian pengobatan diluar tidak diperlukan. Pengobatan sendiri misalnya kerokan, pijat, membuat jamu, membeli obat bebas di warung obat atau apotek. Masyarakat banyak yang pergi ke alternatif karena masyarakat yang masih sederhana, masalah sehat sakit adalah lebih bersifat budaya dari pada gangguan-gangguan fisik. Identik dengan itu pencarian pengobatan pun lebih berorientasi kepada sosial budaya masyarakat daripada hal-hal yang dianggap asing ${ }^{4}$. Penelitian lain yang sejalan menjelaskan usia yang lebih tua dan persepsi tentang mutu pelayanan kesehatan yang baik, merupakan determinan langsung menggunakan layanan kesehatan medis. Status perkawinan, pendidikan, sosial ekonomi, status urban-rural serta pengetahuan tentang TB tidak berhubungan dengan penggunaan kesehatan medis ${ }^{3}$.

Suspek TB yang berpendidikan rendah ternyata mempunyai perilaku mengambil keputusan untuk berobat alternatif. Hal ini menurut pengamatan peneliti sampel yang yang diwawancara adalah golongan umur 45 tahun keatas dan kebanyakan berdomisili di wilayah rural. Hal ini berhubungan dengan masa lalu suspek TB yang tidak dapat melanjutkan pendidikan ke jenjang yang lebih tinggi karena keterbatasan akses ke tempat pendidikan, dan juga keterbatasan ekonomi. Pendidikan berhubungan dengan dengan pengetahuan, sehingga akan menyebabkan kurang tepatnya masyarakat dalam mengambil keputusan untuk berobat atau mencari kesembuhan. Hal ini juga mungkin di dukung juga kurangnya informasi ke masyarakat tentang bahaya penyakit TB, sehingga belum adanya kesadaran untuk segera mencari 
pengobatan atau penyembuhan yang cepat dan akurat agar penyakitnya yag diderita cepat sembuh. Kurangnya informasi tersebut dapat karena keterbatasan tenaga kesehatan, kurang tepatnya sasaran, dan juga karena faktor kesibukan dari masyarakat sendiri. Pengetahuan tentang bahaya penyakit TB yang kurang serta didukung dengan faktor pekerjaan cenderung suspek TB akan mengutamakan pekerjaan dan cenderung melakukan pengobatan sendiri yang dianggap lebih cepat dan terjangkau. Suspek TB mengutamakan gejala hilang dulu tanpa tahu penyakit yang diderita.

Besarnya resiko dapat dilihat dari nilai Ratio Prevalen $(\mathrm{RP})=1,420$ (dengan $\mathrm{Cl} 95 \%$ : $0.849-2,375$ ) dengan demikian Ratio Prevalen $>1$ dan rentang nilai interval kepercayaan mencakup angka 1 yang berarti bahwa pendidikan rendah belum tentu faktor resiko pengambilan keputusan suspek TB untuk melakukan pengobatan ke alternatif.

Hasil secara statistik tidak sama dengan hasil secara teori, bahwa faktor pendidikan merupakan variabel yang mempengaruhi perilaku secara terencana pada diri individu untuk dapat lebih mandiri dalam mencapai tujuan hidup sehat. Konsep dasar pendidikan adalah suatu proses belajar yang berarti dalam terbentuknya proses pertumbuhan, perkembangan atau perubahan kearah yang lebih dewasa, lebih baik dan lebih matang pada diri individu, kelompok atau masyarakat ${ }^{5}$. Pendidikan kesehatan merupakan proses belajar pada individu dari tidak tahu tentang nilai kesehatan dan tidak mampu mengatasi masalah kesehatan sendiri menjadi mandiri. Proses belajar individu dalam meningkatkan ilmunya, tidak hanya diperoleh dari pendidikan formal semata, tetapi dapat juga diperoleh dari pendidikan non formal berupa penyuluhan-penyuluhan kesehatan, seminar kesehatan dan pelatihan kesehatan. Tinggi rendahnya pendidikan seseorang tidak menutup kemungkinan untuk berperilaku baik atau tidak baik, karena yang paling menentukan perilaku seseorang itu sendiri adalah dukungan semangat, dorongan dan perhatian dari pihak keluarga, peran petugas kesehatan serta keinginan yang kuat pada diri.

Penelitian ini sejalan dengan penelitian tentang Survei Perilaku Mencari Pengobatan Individu dengan Gejala Batuk Lebih dari 2 Minggu (Penelitan Komunitas), bahwa usia yang lebih tua dan persepsi tentang mutu pelayanan kesehatan yang baik, merupakan determinan langsung menggunakan layanan kesehatan medis. Status perkawinan, pendidikan, sosial ekonomi, status urban-rural serta pengetahuan tentang TB tidak berhubungan dengan penggunaan kesehatan medis ${ }^{3 .}$

Suspek TB yang ada di komunitas sudah ada kesadaran untuk mencari pengobatan ke pelayanan kesehatan alternatif ketika gejala pertama kali muncul. Status ekonomi dalam penelitian ini tidak berpengaruh karena kebanyakan dari suspek TB pergi ke warung obat/apotik atau meramu jamu jika suspek TB merasakan gejala timbul. Suspek TB menganggap pergi ke warung obat/apotik, meramu jamu sendiri tidak membutuhkan biaya yang mahal dibanding suspek TB harus pergi ke rumah sakit atau fasilitas kesehatan lain, sehingga pendapat tinggi ataupun rendah dalam hal ini tidak ada pengaruhnya. Pengobatan dilakukan secara mandiri oleh suspek TB diasumsikan dapat menghilangkan gejala untuk sementara, padahal untuk penyakit TB, gejala dapat muncul lagi atau bahkan gejala akan menjadi lebih parah.

Konsep respons seseorang terhadap sakit tidak. Orang yang mendapatkan sakit tapi tidak merasakan sakit sudah tentu tidak melakukan upaya apapun terhadap penyakitnya, sebaliknya orang yang mendapatkan sakit tapi merasakan sakit tentu akan berusaha untuk mencari pengobatan. 
Orang yang tidak melakukan upaya untuk penyakitnya karena suspek TB beranggapan bahwa dalam kondisi sakit tidak akan mengganggu aktifitas sehari-hari, tanpa melakukan sesuatu gejala akan hilang sendiri, lebih mengutamakan kegiatan lain dibanding dengan sakitnya, akses fasilitas kesehatan yang sulit dicapai sehingga suspek TB pasrah dengan kondisinya. Selain tidak melakukan apa suspek TB juga ada yang melakukan pengobatan sendiri, pergi ke fasilitas kesehatan baik yang tradisional maupun modern ketika gejala pertama kali muncul ${ }^{5}$.

Besarnya resiko dapat dilihat dari nilai Ratio Prevalen (RP) 1,382 (dengan $\mathrm{Cl}$ 95\% : $0.782-2,442$ ) dengan demikian Ratio Prevalen $>1$ dan rentang nilai interval kepercayaan mencakup angka 1 yang berarti bahwa status ekonomi responden miskin belum tentu merupakan faktor resiko dalam pengambilan keputusan untuk berobat ke alternatif.

Berdasarkan pengamatan dari peneliti tidak ada perbedaan yang bermakna lansia dan bukan lansia dalam pengambilan keputusan. Ada yang melakukan pengobatan ke altenatif, banyak juga yang pergi mencari pengobatan ke apotik/toko obat. Kurangnya pengetahuan tentang TB cenderung menyebabkan suspek TB banyak mencari pengobatan ke apotik/toko obat. Usaha untuk melakukan pengobatan sendiri (self medication), dirasa cukup efektif untuk menghilangkan gejala yang diderita. Tanpa memikirkan efek selanjutnya jika suspek itu benar-benar TB. Sebelum dilakukan pengobatan TB perlu proses yang panjang dalam menentukan apakah suspek benar-banar TB atau bukan. Proses diagnosis TB hanya dimiliki oleh pelayanan kesehatan modern dan tidak ada dalam pelayanan kesehatan tradisonal. Dan TB tidak dapat diobati dengan self medication. Faktor masa lalu yang dapat sembuh dengan pengobatan sendiri (self medication) adalah merupakan faktor kebetulan, gejala yang dulu derita mungkin akan beda dengan gejala yang sekarang derita. Contoh dulu mungkin memang hanya batuk biasa dan dapat diobati dengan dengan obat batuk biasa. Tapi mungkin lain dengan gejala yang sekarang, gejala sama-sama batuk, tapi siapa tahu sekarang sudah terpapar dengan TB dan tidak dapat diobati dengan obat batuk biasa.

Besarnya resiko dapat dilihat dari nilai Ratio Prevalen $(\mathrm{RP})=1,315$ (dengan Cl 95\% : 0,909 - 1,902 ) dengan demikian Ratio Prevalen >1 dan rentang nilai interval kepercayaan mencakup angka 1 yang berarti umur lansia belum tentu merupakan faktor resiko pengambilan keputusan suspek TB untuk melakukan pengobatan alternatif.

\section{SIMPULAN DAN SARAN}

\section{A. Simpulan}

Berdasarkan hasil analisis dan pembahasan faktor - faktor yang berhubungan dengan pengambilan keputusan suspek TB di komunitas untuk tidak berobat ke pelayanan kesehatan alternatif dapat disimpulkan hal-hal sebagai berikut:
a. Tidak ada hubungan antara pendidikan dengan pola pencarian pengobatan ke pelayanan kesehatan alternatif.
b. Tidak ada hubungan antara status ekonomi dengan pola pencarian pengobatan ke pelayanan kesehatan alternatif.
c. Tidak ada hubungan antara jenis kelamin dengan pola pencarian pengobatan ke pelayanan kesehatan alternatif.


d. Tidak ada hubungan antara umur dengan pola pencarian pengobatan ke pelayanan kesehatan alternatif.

\section{B. Saran}

Saran yang dapat diberikan berdasarkan penelitian ini ditujukan bagi Pemerintah DIY /Dinas Kesehatan DIY yaitu perlunya memperluas sasaran promosi kesehatan sampai menjangkau ke segala umur, dari dewasa sampai lansia, dari jenis kelamin perempuan sampai laki-laki. Waktu pelaksanaan juga sampai sore agar sasaran yang paginya bekerja, sepulang bekerja dapat ikut berpartisipasi dalam kegiatan tersebut. Menjadikan sarana pelayanan kesehatan alternatif sebagai mitra dalam penjaringan suspek di komunitas.

Masyarakat dapat meningkatkan pengertian dan kesadaran kepada masyarakat akan bahaya penyakit TB dan segera berobat ke pelayanan kesehatan yang tepat, apabila ada gejala TB atau anggota keluarga yang menunjukan gejala TB. Bagi peneliti selanjutnya perlu dilakukan kajian lebih lanjut mengenai faktor - faktor lain yang menjadi penyebab suspek TB tidak melakukan pengobatan ke pelayanan kesehatan. Faktor-faktor tersebut meliputi pekerjaan, status sosial, status perkawinan, biaya pelayanan, jenis dan beratnya penyakit, jarak fasilitas kesehatan, dan kualitas pelayanan yang dirasakan.

\section{DAFTAR PUSTAKA}

1. Collins, C.D., Green, A.T., Newell, J.N., The Relationship Between Disease Control Strategies and Health System Development the Case of TB, Health Policy Journal, 62(2): 141-60, 2002.

2. Gaffar, Faktor-Faktor yang Berhubungan dengan Perilaku Pencarian Pertolongan Pengobatan Tersangka Penderita TB Paru di Wilayah Kecamatan Banggai Kabupaten Banggai Kepulauan Tahun 2000, Tesis, Universitas Indonesia, 2000.

3. Ahmad, Survei Perilaku Mencari Pengobatan Individu dengan Gejala Batuk Lebih dari 2 Minggu, 2009, www.jurnalkesmas.org/files/KESMAS_VOL_4_NO_1.pdf, diakses 18 Oktober 2013.

4. Notoatmodjo, S., Pengatar Pendidikan dan Perilaku Kesehatan, PT. Rineka Cipta, Jakarta, 2003.

5. Notoatmodjo, S., Metodologi Penelitian Kesehatan, Rineka Cipta, Jakarta, 2010. 